\title{
Metabolic Effects of Human Growth Hormone and of
}

\section{Estrogens in Boys with Duchenne Muscular Dystrophy}

\author{
Daniel Rudman, Samuel B. Chyatte, Joseph H. Patterson, \\ Glynda G. Gerron, Irma O’Beirne, Joan Barlow, Ashby Jordan, and \\ Joel S. Shavin \\ From the Departments of Medicine, Biochemistry, Physical Medicine, and \\ Pediatrics, Emory University School of Medicine and the Clinical Research \\ Facility, Emory University Hospital, Atlanta, Georgia 30322
}

A в S T R A C T Metabolic balance studies were conducted in seven boys with Duchenne-type muscular dystrophy, and in six normal boys of similar age, during a 12 day control period and during a 12 day period of treatment with human growth hormone ( $\mathrm{HGH}$ ) at the following doses : $0.0168,0.0532$, and $0.168 \mathrm{U} / \mathrm{kg}$ body weight (BW) per day (doses $\mathrm{A}, \mathrm{B}$, and $\mathrm{C}$, respectively). In five of the six normals, dose $C$ caused positive balances in $\mathrm{N}, \mathrm{P}, \mathrm{Na}$, and $\mathrm{K}$; doses $\mathrm{B}$ and $\mathrm{A}$ had anabolic effects in two and one normal subjects, respectively. In six of the seven Duchenne cases, dose $C$ caused negative balances of $N$ and $K$, and sometimes of $P$. Negative balances were produced in three of the Duchenne subjects by dose $B$, and in one by dose $A$. None of the dystrophy cases exhibited an anabolic response to any dosage of $\mathrm{HGH}$ tested.

The release of endogenous $\mathrm{HGH}$ in response to insulin, after 2 days' pretreatment with diethylstilbestrol, was similar in both groups of subjects. In the course of these tests, a marked anabolic effect of diethylstilbestrol in the Duchenne patients was apparent. Therefore metabolic balance studies were repeated, in both Duchenne and normal cases, during a 12 day control period and during 12 days of treatment with diethylstilbestrol $(0.106 \mathrm{mg} / \mathrm{kg}$ $\mathrm{BW}$ per day). In three of the normal children, diethylstilbestrol had no effect on the elemental balances; in two cases, a retention of $\mathrm{Na}$ was observed. In all seven Duchenne cases, diethylstilbestrol caused positive balances in $\mathrm{N}, \mathrm{P}, \mathrm{Na}$, and $\mathrm{K}$. Ethinyl estradiol $(0.0106$ $\mathrm{mg} / \mathrm{kg} \mathrm{BW}$ per day) produced positive $\mathrm{N}, \mathrm{P}, \mathrm{Na}$, and

This investigation was supported by U. S. Public Health Service Grants RR 00039 and HD 04485 ; and Health Education and Welfare Department of Research Training and Rehabilitation Grant 16 P 56808/4 07 (RT-6).

Received for publication 14 September 1971 and in revised form 22 November 1971.
$\mathrm{K}$ balances in all three Duchenne cases tested with this agent.

The data show that exogenous $\mathrm{HGH}$ causes a catabolic effect in boys with Duchenne dystrophy. These patients are hyperresponsive to the anabolic effect of diethylstilbestrol. The latter phenomenon may reflect the inhibitory effect of estrogen upon the peripheral actions of these boys' endogenous HGH.

\section{INTRODUCTION}

In a recent study (1) we found that four adult males with myotonic dystrophy were hyperresponsive to the anabolic effects of human growth hormone (HGH) ${ }^{1}$ as measured by changes in balances of $\mathrm{N}, \mathrm{P}, \mathrm{Na}$, and $\mathrm{K}$ and in body weight ( $\mathrm{BW}$ ). In the present investigation, we have measured the effects of $\mathrm{HGH}$ on $\mathrm{N}, \mathrm{P}, \mathrm{Na}$, and $\mathrm{K}$ balance and on $\mathrm{BW}$ in seven patients with a different and more common type of muscular dystrophy, the Duchenne type (2). In the course of these experiments, the patients' endogenous $\mathrm{HGH}$ function was assessed by the insulin-provocative test, after pretreatment with diethylstilbestrol for two days (3). An intense anabolic effect of the brief course of estrogen was observed. Therefore, after completing the measurements of responsiveness to $\mathrm{HGH}$, we measured the metabolic reaction of each boy with Duchenne dystrophy to diethylstilbestrol. A limited number of experiments was also done with ethinyl estradiol. The same studies with $\mathrm{HGH}$ and diethylstilbestrol were done simultaneously with six boys of similar ages, but without muscle disease, who served as controls.

\footnotetext{
${ }^{1}$ Abbreviations used in this paper: BW, body weight; $\mathrm{CPK}$, creatine phosphokinase; EF, extracellular fluid; $\mathrm{HGH}$, human growth hormone; LDH, lactic dehydrogenase.
} 
TABLE I

Clinical Data on the Boys Studied

\begin{tabular}{rrrrrrr}
\hline $\begin{array}{l}\text { Case } \\
\text { No. }\end{array}$ & Age & Height & Weight & Diagnosis & $\begin{array}{c}\text { Muscle } \\
\text { score } \\
(9)^{*}\end{array}$ & $\begin{array}{c}\text { Functional } \\
\text { level } \\
(10)\end{array}$ \\
\hline & $y r$ & inches & $k g$ & & & \\
1 & 6 & 43 & 17 & Duchenne-type muscular dystrophy & 60 & 2 \\
2 & 7 & 44 & 19 & Duchenne-type muscular dystrophy & 30 & 1 \\
3 & 6 & $47 \frac{1}{2}$ & 18 & Duchenne-type muscular dystrophy & 280 & 4 \\
4 & 8 & 47 & 18 & Duchenne-type muscular dystrophy & 230 & 3 \\
5 & 9 & $54 \frac{1}{4}$ & 31 & Duchenne-type muscular dystrophy & 200 & 2 \\
6 & 13 & $55 \frac{1}{2}$ & 29 & Duchenne-type muscular dystrophy & 300 & 4 \\
7 & 9 & $52 \frac{1}{2}$ & 33 & Duchenne-type muscular dystrophy & 180 & 3 \\
8 & 5 & 40 & 15 & Normal & 0 & 1 \\
9 & 7 & $55 \frac{1}{2}$ & 33 & Normal & 0 & 1 \\
10 & 8 & $49 \frac{1}{4}$ & 21 & Normal & 0 & 1 \\
11 & 9 & $56 \frac{1}{2}$ & 34 & Normal & 0 & 1 \\
12 & 13 & $59 \frac{3}{4}$ & 44 & Normal & 0 & 1 \\
13 & 14 & 58 & 34 & Normal & 0 & 1 \\
\hline
\end{tabular}

* Total loss of strength in all 68 muscles tested would give a score of 440 , total normality a score of 0 .

\section{METHODS}

The subjects were seven unrelated boys with Duchenne dystrophy, and six boys without muscle disease, whose clinical data are summarized in Table I. Diagnosis of Duchenne dystrophy was based on: progressive weakness over a 3-7 yr period of observation, particularly apparent in neck flexor, abdominal flexor, gluteus maximus and medius, middle trapezius, and rhomboid musculature; pseudohypertrophy; onset of symptoms before age 8 ; positive family history in brothers and male maternal relatives; elevated serum concentrations of creatine phosphokinase $(\mathrm{CPK})$, lactic dehydrogenase (LDH), and glutamic-oxaloacetic transaminase; electromyographic evidence of myopathy; and confirmatory muscle biopsy in the patient or in an affected male relative.

HGH, lot No. A12, was a gift of the National Pituitary Agency.

To measure the effect of $\mathrm{HGH}$, diethylstilbestrol or ethinyl estradiol on $\mathrm{N}, \mathrm{P}, \mathrm{Na}$, and $\mathrm{K}$ balance, and on $\mathrm{BW}$, the previously described experimental technique (1) was used, except that instead of control and experimental periods of seven days' duration, each period lasted 12 days. The subject consumed the previously specified (1) metabolic balance study diet for 3 days before the control period began. During the control period in every experiment reported here, average daily change in BW did not exceed $\pm 0.04 \mathrm{~kg} / \mathrm{kg} \mathrm{BW} \times 10^{-1}$, and average daily elemental balances were within the following ranges (per $\mathrm{kg}$ $\left.\mathrm{BW} \times 10^{-1}\right): \mathrm{N}, \pm 0.8 \mathrm{~g} ; \mathrm{P}, \pm 0.08 \mathrm{~g} ; \mathrm{Na}, \pm 6.0 \mathrm{mEq} ; \mathrm{K}$, $\pm 2.4 \mathrm{mEq}$. As before, three dosages of $\mathrm{HGH}$ were employed : 0.0168 (dose A), 0.0532 (dose B), and 0.168 (dose C) $\mathrm{U} \mathrm{HGH} / \mathrm{kg} \mathrm{BW}$ per day. The dosages were adjusted to kilogram BW because of the evidence (4) that this unit is more closely related to the subject's metabolic rate than is BW or body surface area. Only one dosage of diethylstilbestrol $(0.106 \mathrm{mg} / \mathrm{kg} \mathrm{BW}$ per day) or of ethinyl estradiol $(0.0106 \mathrm{mg} / \mathrm{kg} \mathrm{BW}$ per day) was used. This dose of ethinyl estradiol was selected, after completion of the experiments with diethylstilbestrol, on the basis that the estrogenic potency of the former is about 10 times greater than that of the latter. $\mathrm{HGH}$ was administered intramuscularly at 8:00 a.m. The estrogens were given orally in equally divided doses at 9:00 a.m. and 6:00 p.m. Effects of these hormones on elemental balances and BW, expressed as $\Delta \mathrm{N}, \Delta \mathrm{P}, \Delta \mathrm{Na}, \Delta \mathrm{K}$, and $\Delta \mathrm{BW}$ per $\mathrm{kg} \mathrm{BW} \times$ $10^{-1}$ per day, were calculated as in the previous study (1).

Urinary urea and ammonia were measured according to references 5 and 6 , respectively.

Activities of $\mathrm{CPK}$ and $\mathrm{LDH}$ in fasting serum were measured by the methods of Rosalski (7), and Wacker, Ulmer, and Vallee (8), respectively.

In the dystrophy cases, strength of 68 muscles was measured before and upon completion of each course of hormone treatment. Score of muscle strength was graded on a scale of 0 to 440 according to Lilienfeld, Jacobs, and Willis (9). Functional ability was graded on a scale of 1 to 8 according to Swinyard, Deaver, and Greenspan (10).

\section{RESULTS}

Effects of $H G H$. The effects of $\mathrm{HGH}$ on $\mathrm{N}, \mathrm{P}, \mathrm{Na}$, and $\mathrm{K}$ balance, and on $\mathrm{BW}$, of seven boys with $\mathrm{Du}$ chenne dystrophy are shown in Table II. In six of the seven subjects, dose $C$ caused a significant ${ }^{2}$ reduction in balances of $\mathrm{N}$ and $\mathrm{K}$, and sometimes of $\mathrm{P}$. Reductions in balances for $\mathrm{N}, \mathrm{P}$, and $\mathrm{K}$ were produced in three and in one of the Duchenne subjects by doses B and A, respectively. None of the dystrophy cases exhibited an

${ }^{2}$ The criterion for a significant (negative or positive) response in terms of $\Delta \mathrm{N}, \Delta \mathrm{P}, \Delta \mathrm{Na}$, or $\Delta \mathrm{K}$ was : $P<0.05$ for the difference (or $\Delta$ ), between average daily balance during experimental period $(n=12)$ and average daily balance during control period $(n=12)$. Since the variance of $\triangle \mathrm{BW}$ was not measured (1), the $P$ value for this index of response could not be estimated. $\triangle B W Z \pm 0.05 \mathrm{~kg} / \mathrm{kg}$ $\mathrm{BW} \times 10^{-1}$ per day was considered noteworthy, since no subject studied showed a change in $B W> \pm 0.04 \mathrm{~kg} / \mathrm{kg}$ $B W^{3} \times 10^{-1}$ per day during the 12 day control period. 
TABLE II

Effects of $H G H$ and Estrogen on Elemental Balances and $B W$

\begin{tabular}{|c|c|c|c|c|c|c|c|}
\hline \multirow{2}{*}{$\begin{array}{l}\text { Case } \\
\text { No. }\end{array}$} & \multirow{2}{*}{$\begin{array}{l}\text { Experi- } \\
\text { ment } \\
\text { No. }\end{array}$} & \multirow[b]{2}{*}{ Treatment } & \multicolumn{5}{|c|}{$\begin{array}{c}\text { Changes in balances and } \mathrm{BW} \text { per kg BW } \times 10^{-1} \text { per day during experimental period } \\
\text { (Values are average } \pm \mathrm{SE}[\mathrm{n}=12])\end{array}$} \\
\hline & & & $\Delta \mathrm{N}$ & $\Delta \mathbf{P}$ & $\Delta \mathrm{Na}$ & $\Delta \mathrm{K}$ & $\Delta \mathrm{BW}$ \\
\hline 1 & $\begin{array}{l}1-A \\
1-B \\
1-C \\
1-D\end{array}$ & $\begin{array}{l}\text { HGH (dose A) } \\
\text { HGH (dose B) } \\
\text { HGH (dose C) } \\
\text { diethylstilbestrol }\end{array}$ & $\begin{array}{l}g \\
-0.6 \pm 0.1^{*} \\
-0.8 \pm 0.2^{*} \\
-1.4 \pm 0.3^{*} \\
+1.2 \pm 0.3^{*}\end{array}$ & $\begin{array}{c}g \\
-0.036 \pm 0.01 \\
-0.06 \pm 0.01^{*} \\
-0.098 \pm 0.03^{*} \\
+0.12 \pm 0.04^{*}\end{array}$ & $\begin{array}{c}m E q \\
+2.1 \pm 3.5 \\
-3.6 \pm 2.1 \\
-2.0 \pm 0.4 \\
+10.2 \pm 2.4^{*}\end{array}$ & $\begin{array}{c}m E q \\
-3.0 \pm 1.0 \\
-3.2 \pm 0.9^{*} \\
-5.0 \pm 1.1^{*} \\
+4.0 \pm 1.2^{*}\end{array}$ & $\begin{array}{c}k g \\
0.00 \\
-0.03 \\
-0.03 \\
+0.084\end{array}$ \\
\hline 2 & $\begin{array}{l}2-A \\
2-B\end{array}$ & $\begin{array}{l}\text { HGH (dose C) } \\
\text { diethylstilbestrol }\end{array}$ & $\begin{array}{l}-1.1 \pm 0.2^{*} \\
+1.4 \pm 0.3^{*}\end{array}$ & $\begin{array}{l}-0.06 \pm 0.03 \\
+0.15 \pm 0.05^{*}\end{array}$ & $\begin{array}{l}+2.5 \pm 2.2 \\
+7.2 \pm 2.9^{*}\end{array}$ & $\begin{array}{l}-5.1 \pm 1.4^{*} \\
+4.0 \pm 1.3^{*}\end{array}$ & $\begin{array}{l}+0.01 \\
+0.05\end{array}$ \\
\hline 3 & $\begin{array}{l}3-A \\
3-B \\
3-C \\
3-D \\
3-E\end{array}$ & $\begin{array}{l}\text { HGH (dose A) } \\
\text { HGH (dose B) } \\
\text { HGH (dose C) } \\
\text { diethylstilbestrol } \\
\text { ethinyl estradiol }\end{array}$ & $\begin{array}{l}+0.1 \pm 0.1 \\
-0.5 \pm 0.2 \\
-1.4 \pm 0.2^{*} \\
+1.1 \pm 0.3^{*} \\
+1.6 \pm 0.3^{*}\end{array}$ & $\begin{aligned}-0.01 & \pm 0.004 \\
-0.03 & \pm 0.01 \\
-0.09 & \pm 0.02^{*} \\
+0.12 & \pm 0.03^{*} \\
+0.09 & \pm 0.2^{*}\end{aligned}$ & $\begin{array}{r}+3.3 \pm 3.0 \\
+2.2 \pm 0.8 \\
-2.9 \pm 1.9 \\
+8.5 \pm 2.1^{*} \\
+12.7 \pm 2.7^{*}\end{array}$ & $\begin{array}{l}-1.1 \pm 1.0 \\
-2.5 \pm 0.7 \\
-5.5 \pm 1.3^{*} \\
+3.6 \pm 1.9 \\
+8.1 \pm 1.7^{*}\end{array}$ & $\begin{array}{r}0.01 \\
-0.02 \\
-0.03 \\
+0.05 \\
+0.06\end{array}$ \\
\hline 4 & $\begin{array}{l}4-A \\
4-B\end{array}$ & $\begin{array}{l}\text { HGH (dose C) } \\
\text { diethylstilbestrol }\end{array}$ & $\begin{array}{l}-1.0 \pm 0.1^{*} \\
+0.9 \pm 0.1^{*}\end{array}$ & $\begin{array}{l}-0.05 \pm 0.02^{*} \\
+0.09 \pm 3^{*}\end{array}$ & $\begin{array}{l}-1.6 \pm 2.3 \\
+7.2 \pm 2.1^{*}\end{array}$ & $\begin{array}{l}-4.4 \pm 1.1^{*} \\
+3.3 \pm 0.9\end{array}$ & $\begin{array}{l}-0.02 \\
+0.04\end{array}$ \\
\hline 5 & $\begin{array}{l}5-A \\
5-B \\
5-C \\
5-D \\
5-E\end{array}$ & $\begin{array}{l}\text { HGH (dose A) } \\
\text { HGH (dose B) } \\
\text { HGH (dose C) } \\
\text { diethylstilbestrol } \\
\text { ethinyl estradiol }\end{array}$ & $\begin{array}{l}-0.10 \pm 0.1 \\
-1.0 \pm 0.2^{*} \\
-1.6 \pm 0.4^{*} \\
+0.9 \pm 0.2^{*} \\
+1.4 \pm 0.3^{*}\end{array}$ & $\begin{array}{l}+0.01 \pm 0.005 \\
-0.07 \pm 0.03 \\
-0.09 \pm 0.02^{*} \\
+0.10 \pm 0.03^{*} \\
+0.16 \pm 0.04^{*}\end{array}$ & $\begin{array}{l}+3.1 \pm 2.1 \\
-4.5 \pm 3.0 \\
+1.5 \pm 1.1 \\
+8.0 \pm 2.3^{*} \\
+6.5 \pm 2.0^{*}\end{array}$ & $\begin{array}{l}-1.1 \pm 2.0 \\
-4.1 \pm 2.7 \\
-5.5 \pm 1.9^{*} \\
+6.5 \pm 2.1^{*} \\
+5.7 \pm 1.4^{*}\end{array}$ & $\begin{array}{r}0.00 \\
-0.02 \\
-0.03 \\
-0.05 \\
-0.04\end{array}$ \\
\hline 6 & $\begin{array}{l}6-A \\
6-B \\
6-C \\
6-D \\
6-E\end{array}$ & $\begin{array}{l}\text { HGH (dose A) } \\
\text { HGH (dose B) } \\
\text { HGH (dose C) } \\
\text { diethylstilbestrol } \\
\text { ethinyl estradiol }\end{array}$ & $\begin{array}{r}0.00 \pm 0.1 \\
-0.3 \pm 0.1 \\
-1.3 \pm 0.3^{*} \\
+1.0 \pm 0.2^{*} \\
+0.8 \pm 0.2^{*}\end{array}$ & $\begin{aligned}+0.01 & \pm 0.002 \\
0.00 & \pm 0.02 \\
-0.05 & \pm 0.01^{*} \\
+0.11 & \pm 0.03^{*} \\
+0.07 & \pm 0.02^{*}\end{aligned}$ & $\begin{array}{r}-5.2 \pm 3.5 \\
+2.6 \pm 3.1 \\
-4.1 \pm 3.0 \\
+10.1 \pm 2.4^{*} \\
+6.5 \pm 1.9^{*}\end{array}$ & $\begin{array}{l}+1.1 \pm 2.4 \\
-5.1 \pm 1.3^{*} \\
-7.4 \pm 1.4^{*} \\
+5.1 \pm 1.0^{*} \\
+3.0 \pm 1.1^{*}\end{array}$ & $\begin{array}{r}0.00 \\
-0.01 \\
-0.02 \\
-0.05 \\
-0.05\end{array}$ \\
\hline 7 & $\begin{array}{l}7-A \\
7-B\end{array}$ & $\begin{array}{l}\text { HGH (dose C) } \\
\text { diethylstilbestrol }\end{array}$ & $\begin{array}{l}+0.1 \pm 0.2 \\
+1.1 \pm 0.3^{*}\end{array}$ & $\begin{array}{l}+0.04 \pm 0.03 \\
+0.10 \pm 0.02^{*}\end{array}$ & $\begin{array}{l}+3.1 \pm 1.9 \\
+8.1 \pm 2.6^{*}\end{array}$ & $\begin{array}{l}+1.0 \pm 2.4 \\
+5.5 \pm 1.1^{*}\end{array}$ & $\begin{array}{r}0.00 \\
+0.04\end{array}$ \\
\hline 8 & $\begin{array}{l}8-A \\
8-B \\
8-C \\
8-D\end{array}$ & $\begin{array}{l}\text { HGH (dose A) } \\
\text { HGH (dose B) } \\
\text { HGH (dose C) } \\
\text { diethylstilbestrol }\end{array}$ & $\begin{array}{l}+0.5 \pm 0.3 \\
+0.5 \pm 0.2 \\
+1.1 \pm 0.2^{*} \\
+0.1 \pm 0.1\end{array}$ & $\begin{array}{l}+0.05 \pm 0.03 \\
+0.07 \pm 0.03 \\
+0.14 \pm 0.04^{*} \\
-0.02 \pm 0.01\end{array}$ & $\begin{array}{l}+3.6 \pm 3.0 \\
+8.5 \pm 1.9^{*} \\
+8.9 \pm 2.4^{*} \\
+3.1 \pm 2.7\end{array}$ & $\begin{array}{l}+4.1 \pm 2.0 \\
+6.3 \pm 3.9 \\
+4.7 \pm 1.8^{*} \\
+1.1 \pm 0.3\end{array}$ & $\begin{array}{r}0.00 \\
+0.05 \\
+0.06 \\
+0.02\end{array}$ \\
\hline 9 & $\begin{array}{l}9-A \\
9-B \\
9-C \\
9-D\end{array}$ & $\begin{array}{l}\text { HGH (dose A) } \\
\text { HGH (dose B) } \\
\text { HGH (dose C) } \\
\text { diethylstilbestrol }\end{array}$ & $\begin{array}{l}+0.1 \pm 0.1 \\
+1.1 \pm 0.3^{*} \\
+1.8 \pm 0.2^{*} \\
+0.1 \pm 0.1\end{array}$ & $\begin{array}{l}-0.02 \pm 0.01 \\
-0.05 \pm 0.02 \\
+0.17 \pm 0.03^{*} \\
+0.05 \pm 0.02\end{array}$ & $\begin{array}{l}-3.5 \pm 2.7 \\
+8.3 \pm 2.0^{*} \\
+7.0 \pm 1.9^{*} \\
+9.9 \pm 2.4^{*}\end{array}$ & $\begin{array}{l}+2.7 \pm 1.1 \\
+2.9 \pm 2.3 \\
+5.3 \pm 1.3^{*} \\
-1.1 \pm 0.9\end{array}$ & $\begin{array}{r}0.00 \\
+0.06 \\
+0.05 \\
+0.05\end{array}$ \\
\hline 10 & $\begin{array}{l}10-\mathrm{A} \\
10-\mathrm{B} \\
10-\mathrm{C} \\
10-\mathrm{D}\end{array}$ & $\begin{array}{l}\text { HGH (dose A) } \\
\text { HGH (dose B) } \\
\text { HGH (dose C) } \\
\text { diethylstilbestrol }\end{array}$ & $\begin{array}{l}+0.6 \pm 0.1^{*} \\
+0.7 \pm 0.3^{*} \\
+1.1 \pm 0.2^{*} \\
+0.3 \pm 0.2\end{array}$ & $\begin{array}{l}+0.05 \pm 0.01^{*} \\
+0.08 \pm 0.02^{*} \\
+0.10 \pm 0.02^{*} \\
+0.018 \pm 0.006\end{array}$ & $\begin{array}{l}+5.5 \pm 2.9 \\
+9.0 \pm 2.8^{*} \\
+8.9 \pm 2.0^{*} \\
+7.1 \pm 2.4^{*}\end{array}$ & $\begin{array}{l}+3.3 \pm 2.4 \\
+3.8 \pm 1.9 \\
+7.0 \pm 1.5^{*} \\
+2.3 \pm 2.0\end{array}$ & $\begin{array}{l}+0.02 \\
+0.05 \\
+0.04 \\
+0.05\end{array}$ \\
\hline 11 & $\begin{array}{l}11-\mathrm{A} \\
11-\mathrm{B} \\
11-\mathrm{C} \\
11-\mathrm{D}\end{array}$ & $\begin{array}{l}\text { HGH (dose A) } \\
\text { HGH (dose B) } \\
\text { HGH (dose C) } \\
\text { diethylstilbestrol }\end{array}$ & $\begin{array}{c}+0.2 \pm 0.1 \\
0.00 \pm 0.1 \\
+1.6 \pm 0.3^{*} \\
+0.4 \pm 0.2\end{array}$ & $\begin{aligned} 0.00 & \pm 0.01 \\
-0.03 & \pm 0.02 \\
+0.20 & \pm 0.04^{*} \\
+0.06 & \pm 0.03\end{aligned}$ & $\begin{array}{l}+3.7 \pm 3.6 \\
+3.4 \pm 2.5 \\
+6.8 \pm 2.3^{*} \\
+3.2 \pm 1.8\end{array}$ & $\begin{array}{l}-3.2 \pm 1.9 \\
+3.5 \pm 2.0 \\
+5.5 \pm 1.7^{*} \\
+4.1 \pm 2.5\end{array}$ & $\begin{array}{r}+0.02 \\
0.00 \\
+0.04 \\
+0.03\end{array}$ \\
\hline 12 & $\begin{array}{l}12-\mathrm{A} \\
12-\mathrm{B} \\
12-\mathrm{C} \\
12-\mathrm{D}\end{array}$ & $\begin{array}{l}\text { HGH (dose A) } \\
\text { HGH (dose B) } \\
\text { HGH (dose C) } \\
\text { diethylstilbestrol }\end{array}$ & $\begin{aligned}+0.3 & \pm 0.1 \\
+0.2 & \pm 0.1 \\
+0.3 & \pm 0.2 \\
0.00 & \pm 0.1\end{aligned}$ & $\begin{array}{r}0.00 \pm 0.02 \\
+0.03 \pm 0.01 \\
+0.00 \pm 0.02 \\
+0.02 \pm 0.01\end{array}$ & $\begin{array}{c}+4.4 \pm 3.0 \\
+3.5 \pm 2.9 \\
+1.7 \pm 1.9 \\
+10.1 \pm 3.0^{*}\end{array}$ & $\begin{array}{r}+3.6 \pm 2.6 \\
-1.5 \pm 1.8 \\
+3.3 \pm 1.2 \\
-2.6 \pm 2.0\end{array}$ & $\begin{array}{r}+0.02 \\
0.00 \\
-0.01 \\
+0.05\end{array}$ \\
\hline
\end{tabular}


TABLE II-(Continued)

\begin{tabular}{|c|c|c|c|c|c|c|c|}
\hline \multirow{2}{*}{$\begin{array}{l}\text { Case } \\
\text { No. }\end{array}$} & \multirow{2}{*}{$\begin{array}{l}\text { Experi- } \\
\text { ment } \\
\text { No. }\end{array}$} & \multirow[b]{2}{*}{ Treatment } & \multicolumn{5}{|c|}{$\begin{array}{c}\text { Changes in balances and } \mathrm{BW} \text { per } \mathrm{kg} \mathrm{BW}^{\frac{3}{2}} \times 10^{-1} \text { per day during experimental period } \\
\text { (Values are average } \pm \operatorname{SE}[\mathrm{n}=12])\end{array}$} \\
\hline & & & $\Delta \mathrm{N}$ & $\Delta \mathrm{P}$ & $\Delta \mathrm{Na}$ & $\Delta \mathbf{K}$ & $\Delta \mathrm{BW}$ \\
\hline \multirow{5}{*}{13} & & & $g$ & $g$ & $m E q$ & $m E q$ & \\
\hline & 13-A & HGH (dose A) & $0.00 \pm 0.1$ & $+0.03 \pm 0.01$ & $-3.1 \pm 1.8$ & $+2.2 \pm 1.9$ & -0.01 \\
\hline & 13-B & HGH (dose B) & $+0.1 \pm 0.1$ & $-0.02 \pm 0.01$ & $+2.6 \pm 2.5$ & $+4.9 \pm 2.8$ & +0.02 \\
\hline & $13-\mathrm{C}$ & HGH (dose C) & $+0.9 \pm 0.2^{*}$ & $+0.10 \pm 0.02^{*}$ & $+6.5 \pm 2.0^{*}$ & $+5.6 \pm 1.7^{*}$ & +0.04 \\
\hline & $13-\mathrm{D}$ & diethylstilbestrol & $0.00 \pm 0.1$ & $+0.03 \pm 0.01$ & $+2.4 \pm 2.7$ & $+1.1 \pm 2.0$ & +0.03 \\
\hline
\end{tabular}

* $P<0.05$ for difference $(\Delta)$ between average elemental balance during experimental and control periods.

anabolic response to any dosage of $\mathrm{HGH}$ tested. In none of the dystrophic subjects did BW change by more than $0.03 \mathrm{~kg} / \mathrm{kg} \mathrm{BW} \times 10^{-1}$ per day.

The effects of $\mathrm{HGH}$ on balances (i.e. $\Delta \mathrm{N}, \Delta \mathrm{P}, \Delta \mathrm{Na}$, and $\Delta \mathrm{K}$ ) shown in Table II represent the average daily balance during experimental period minus the average daily balance during control period (1). The declines in elemental balances observed in 10 of the 14 experiments (i.e. all but experiments No. 3-A, No. 3-B, No. 5-A, and No. 7-A) became apparent on the 2nd to 5th day of $\mathrm{HGH}$ treatment. The negative balances, once apparent, persisted for the remainder of the experimental period. In four experiments at dose $\mathrm{C}$, metabolic balance study continued for an additional 10 days after $\mathrm{HGH}$ was stopped. Elemental balances returned to those of the control period 3-8 days after HGH was stopped.

Muscle strength scores and levels of serum CPK and $\mathrm{LDH}$ were not influenced by $\mathrm{HGH}$, and the patients were clinically unchanged.

None of the dystrophic patients showed detectable ketonuria during $\mathrm{HGH}$ treatment. In experiments No. 1-C, No. 3-C, and No. 5-C, urinary urea and ammonia were measured as well as urinary total $\mathrm{N}$. Urea $\mathrm{N}$ constituted $76-85 \%$, and ammonia $\mathrm{N} 3-6 \%$ of total urinary $\mathrm{N}$ throughout these experiments. The increase in urinary $\mathrm{N}$ during $\mathrm{HGH}$ treatment resulted from an increase in urinary urea, without change in urinary ammonia.

In five of the six normal subjects (cases No. 8 to No. 13 ), dose $\mathrm{C}$ caused positive balances in $\mathrm{N}, \mathrm{P}, \mathrm{Na}$, and $\mathrm{K}$, with associated weight gain of $0.04-0.06 \mathrm{~kg} / \mathrm{kg}$ BW $\times 10^{-1}$ per day. Doses B and A produced anabolic effects in two and in one normal subjects, respectively. These results are in general agreement with those previously reported in four normal boys and girls 9-13 yr old (1). In all experiments in cases No. 8 to No. 13 where a dose of HGH produced positive metabolic balances, the effect was apparent during the first $24 \mathrm{hr}$ of hormone treatment.

Effects of diethylstilbestrol and ethinyl estradiol. All subjects were pretreated with $2.5 \mathrm{mg}$ diethylstilbestrol orally twice a day for 2 days before the insulin-provocative test. Peak plasma $\mathrm{HGH}$ values during the $90 \mathrm{~min}$ after insulin (0.1 U/kg BW intravenously) did not differ significantly between the dystrophy group (average $\pm \mathrm{SE}, 10.2 \pm 2.6[\mathrm{n}=7]$ ) and the control group (average \pm SE, $12.5 \pm 3.2[n=6])$. Dystrophic cases No. 2 and No. 4 were in the preliminary stages of a balance study during the diethylstilbestrol pretreatment, and it was noted that $\mathrm{N}, \mathrm{P}, \mathrm{Na}$, and $\mathrm{K}$ balances became markedly positive in both subjects within $24 \mathrm{hr}$ after the drug was started. Therefore, the effect of a 12 day course of diethylstilbestrol on balances and on BW was investigated in all 13 subjects. Initially an oral dose of 0.530 $\mathrm{mg} / \mathrm{kg} \mathrm{BW}$ per day (corresponding to $5.0 \mathrm{mg} /$ day for a $20 \mathrm{~kg}$ subject) was tested, but anorexia and nausea were troublesome. Therefore $0.106 \mathrm{mg} / \mathrm{kg}$ BW per day was adopted for the experiments summarized in Table II. At this dose all subjects were able to maintain complete intake of the prescribed diet (1) during the 12 day experimental period of the balance study.

Diethylstilbestrol caused increases in the balances of $\mathrm{N}, \mathrm{P}, \mathrm{Na}$, and $\mathrm{K}$, and increase in $\mathrm{BW}$, in all seven dystrophic subjects. In three of the six control subjects, elemental balances and BW were not influenced by diethylstilbestrol; in three subjects an increase in $\mathrm{Na}$ balance and in BW, without change in $\mathrm{N}, \mathrm{P}$, or $\mathrm{K}$ balance, was observed.

The effects on elemental balances and BW were evident in all dystrophic cases during the first $24 \mathrm{hr}$ after the estrogen was begun and persisted for the entire 12 days of treatment. In the control subjects, the effects on $\mathrm{Na}$ balance and on BW were not detected until the 3rd to 4th day of treatment. In both groups, after estrogens were stopped, balances returned to control levels over a period of 2-5 days and the increment in BW was lost over a period of 7-10 days.

Serum CPK and LDH levels in dystrophic subject No. 3 were significantly lower $(P<0.05)$ during the course of diethylstilbestrol (average 2145 and $290 \mathrm{mU} / \mathrm{ml}$, respectively) than during the control period (average 6300 and $560 \mathrm{mU} / \mathrm{ml}$, respectively), but in the other six dystrophic cases serum enzyme levels were not significantly influenced. Score of muscle strength did not change appreciably in five of the dystrophy patients; in cases No. 
TABLE III

Comparison of Response of Duchenne Patients and Normal Subjects to Dose C of HGH and to Diethylstilbestrol*

\begin{tabular}{|c|c|c|c|c|c|c|c|c|}
\hline \multirow[b]{2}{*}{ Subjects } & \multirow[b]{2}{*}{ Treatment } & \multicolumn{7}{|c|}{ Response per kg BW $\mathrm{BW}^{\frac{3}{4}} \times 10^{-1}$ per day } \\
\hline & & $\Delta \mathrm{N}$ & $\Delta \mathbf{P}$ & $\Delta \mathrm{Na}$ & $\Delta \mathrm{K}$ & $\Delta$ Protoplasm & $\Delta$ Bone & $\Delta \mathrm{EF}$ \\
\hline Duchenne & HGH (dose C) & $\begin{array}{l}\quad g \\
-1.1 \\
\pm 0.02\end{array}$ & $\begin{array}{c}\boldsymbol{g} \\
-0.06 \\
\pm 0.019\end{array}$ & $\begin{array}{c}m E q \\
-0.5 \\
\pm 1.1\end{array}$ & $\begin{array}{c}m E q \\
-4.6 \\
\pm 1.0\end{array}$ & $\begin{array}{c}\text { g } \\
-29.7 \\
\pm 5.8\end{array}$ & $\begin{array}{c}g \\
+0.21 \\
\pm 0.02\end{array}$ & $\begin{array}{c}g \\
+6 \pm 5.7\end{array}$ \\
\hline Normal & HGH (dose C) & $\begin{array}{l}+1.1 \\
\pm 0.21\end{array}$ & $\begin{array}{l}+0.12 \\
\pm 0.028\end{array}$ & $\begin{array}{l}+6.6 \\
\pm 1.05\end{array}$ & $\begin{array}{l}+5.2 \\
\pm 0.49\end{array}$ & $\begin{array}{r}+30.6 \\
\pm 4.8\end{array}$ & $\begin{array}{l}+0.26 \\
\pm 0.31\end{array}$ & $+44 \pm 7.2$ \\
\hline$P \ddagger$ & HGH (dose C) & $P<0.001$ & $P<0.001$ & $P<0.001$ & $P<0.001$ & $P<0.001$ & NS & $P<0.004$ \\
\hline Duchenne & diethylstilbestrol & $\begin{array}{l}+1.1 \\
\pm 0.07\end{array}$ & $\begin{array}{l}+0.11 \\
\pm 0.019\end{array}$ & $\begin{array}{l}+8.5 \\
\pm 0.46\end{array}$ & $\begin{array}{l}+4.6 \\
\pm 0.43\end{array}$ & $\begin{array}{r}+29.3 \\
\pm 1.9\end{array}$ & $\begin{array}{l}+0.95 \\
\pm 0.57\end{array}$ & $+56 \pm 3.1$ \\
\hline Normal & diethylstilbestrol & $\begin{array}{l} \pm 0.2 \\
\pm 0.04\end{array}$ & $\begin{array}{l}+0.03 \\
\pm 0.012\end{array}$ & $\begin{array}{l}+5.2 \\
\pm 1.9\end{array}$ & $\begin{array}{l}+0.8 \\
\pm 0.96\end{array}$ & $\begin{array}{l}+4.1 \\
\pm 1.4\end{array}$ & $\begin{array}{l}+0.19 \\
\pm 0.12\end{array}$ & $+34 \pm 12.8$ \\
\hline$P \ddagger$ & diethylstilbestrol & $P<0.001$ & $P<0.005$ & NS & $P<0.005$ & $P<0.001$ & NS & NS \\
\hline
\end{tabular}

* Values are average $\pm \mathrm{SE} ; \mathrm{n}=7$ and 6 for Duchenne and normal subjects, respectively.

$\ddagger P$ value for difference between specified response of Duchenne and control groups. NS signifies $P>0.05$.

2 and No. 4, muscle score improved by $10-20 \%$ after 12 days of diethylstilbestrol.

Three of the dystrophic boys were treated (after a control period) with ethinyl estradiol for 12 days. This estrogen produced positive elemental balances and gain in BW similar to those produced by diethylstilbestrol at 10 times higher dose. Muscle strength did not change detectably.

Both estrogens caused a slight gynecomastia and occasional nausea during the 2 wh period of estrogen treatment.

Table III compares the responses of dystrophic and normal subjects to $\mathrm{HGH}$ (dose C) and to diethylstilbestrol. The two groups differ significantly $(P<0.005)$ in response of $\Delta \mathrm{N}, \Delta \mathrm{P}, \Delta \mathrm{Na}$, and $\Delta \mathrm{K}$ to $\mathrm{HGH}$ and in response of $\Delta \mathrm{N}, \Delta \mathrm{P}$, and $\Delta \mathrm{K}$ to diethylstilbestrol.

\section{DISCUSSION}

In an earlier study, four patients with myotonic dystrophy exhibited hyperresponsiveness to the anabolic effects of HGH, compared to normal controls (1). This intense anabolic response, with simultaneous improvement in the EKG, has raised the possibility that $\mathrm{HGH}$ might have therapeutic value in myotonic dystrophy. The present subjects with Duchenne-type dystrophy also differ from normal in their response to $\mathrm{HGH}$, but in the opposite direction: in six of seven cases at dose $\mathrm{C}$, and in some instances at doses $\mathrm{B}$ and $\mathrm{A}$, the hormone caused negative balances in $\mathrm{N}$, in $\mathrm{K}$, and sometimes in $\mathrm{P}$.

Negative $\mathrm{N}$ balance during $\mathrm{HGH}$ treatment does not necessarily signify a catabolic effect, as shown by the observations of Felig, Marliss, and Cahill (14). These investigators found that when fasting obese subjects were treated with $\mathrm{HGH}$, ketonuria appeared (reflecting the adipokinetic effect of the hormone) ; urinary urea $\mathrm{N}$ declined (manifesting the anabolic effect of $\mathrm{HGH}$ ) ; urinary ammonia $\mathrm{N}$ increased (as more ammonium ions were excreted in association with ketone bodies); and total urinary $N$, the sum of urea $N$, ammonia $N$, and other constituents, remained unchanged. In the present experiments with fed dystrophic boys, however, ketonuria did not occur, the increase in urinary $\mathrm{N}$ was caused by increased excretion of urea without change in ammonia, and the negative balance of $\mathrm{N}$ was accompanied by negative balances of two other principal intracellular elements, $P$ and $K$. These considerations indicate that $\mathrm{HGH}$ did in fact cause a catabolic effect in the dystrophic patients.

From the magnitude of $\Delta \mathrm{N}, \Delta \mathrm{P}$, and $\Delta \mathrm{Na}$, it is possible to estimate the changes in mass of $(a)$ protoplasm, (b) bone, and (c) extracellular fluid (EF) which occurred during the period of hormone treatment (11).: These calculations showed (Table III) that the major effect of

\footnotetext{
${ }^{3}$ The equations for these calculations are $(11,12)$ :

$\Delta$ protoplasm $(\mathrm{g})=27 \Delta \mathrm{N}$.

$\Delta$ bone $(\mathrm{g})=11.5(\Delta \mathrm{P}-0.068 \Delta \mathrm{N})$.

$\Delta \mathrm{EF}(\mathrm{g})=6.62 \Delta \mathrm{Na}$.

$\Delta \mathrm{N}, \Delta \mathrm{P}$, and $\Delta \mathrm{Na}$ are expressed in $\mathrm{g}, \mathrm{g}$, and $\mathrm{mEq}$, respectively (1). Horvath, Cummings, and Shy (13) reported that in the muscle cells of 20 patients with unspecified type(s) of muscular dystrophy, the concentration of $K$ was less than and of $\mathrm{Na}$ greater than those in normal muscle cells. To the extent that this abnormality in electrolyte composition was present in the muscle cells of the Duchenne patients studied here, the third equation will overestimate $\triangle \mathrm{EF}$ in these individuals.
} 
$\mathrm{HGH}$ in the muscular dystrophy patients was a loss of protoplasm. In the normal subjects, major increments in both protoplasm and extracellular fluid were observed, as previously noted (1).

Circumstances, such as hypercortisolism or malnutrition, which inhibit the anabolic effect of $\mathrm{HGH}$ in man are now recognized (reviewed in reference 1 ). But a catabolic response to $\mathrm{HGH}$ in human subjects, or to other types of growth hormone in animals, has not been described before. The mechanism for this paradoxical effect in boys with Duchenne dystrophy needs investigation. Simon, Gross, and Lessell found (15) that in mice with hereditary muscular dystrophy, muscle proteins turned over about 3 times more rapidly than in normal mice. They concluded that catabolism of muscle protein was accelerated in this condition, and that there was no impediment to protein synthesis within these dystrophic muscle cells. Confirmatory findings in the mouse with hereditary dystrophy were reported by Kruh, Dreyfus, Schapira, and Gey (16), Coleman and Ashworth (17), and Watts and Reid (18). Weinstock, Epstein, and Milhorat (19) observed an increase in proteolytic activity in muscles of dystrophic mice, as did Berlingult and Srivastava subsequently (20), and proposed that this change caused the abnormally rapid turnover of the muscle proteins. Growth hormone stimulates the synthesis of a variety of proteins in normal muscle cells of the rat (21). Whether the hormone stimulates synthesis of proteolytic enzymes in muscle is not yet reported. One type of explanation for the present finding of a catabolic effect of HGH in boys with Duchenne dystrophy might postulate accelerated synthesis, under the influence of the hormone, of proteolytic enzymes in the dystrophic muscle cells. If, under the influence of $\mathrm{HGH}$, the activities of these degradative enzymes should increase out of proportion to those of enzymes involved in protein synthesis, then a net loss of muscle protoplasm could ensue.

The catabolic response to HGH not only suggests that the exogenous hormone would not be useful in treatment of Duchenne dystrophy, but also raises the possibility that endogenous $\mathrm{HGH}$ may be involved in the pathogenesis of the disease.

The rationale for investigating the effect of estrogens in these subjects had a dual origin: (a) the chance observation that pretreatment of Duchenne patients with estrogens in preparation for insulin-provocative tests caused a pronounced anabolic response; $(b)$ the idea was already under consideration, as mentioned above, that endogenous $\mathrm{HGH}$ might be adversely influencing the dystrophic muscle cells of these subjects with $\mathrm{Du}$ chenne dystrophy. Several studies in rat and man (22) have suggested that estrogens inhibit peripheral actions of $\mathrm{HGH}$. Therefore it seemed possible that an adverse effect of endogenous HGH on muscle cells of Duchenne boys could be inhibited by estrogens.

Previous studies $(23,24)$ have shown that estrogens, besides stimulating female reproductive structures, have three general metabolic effects: (a) Deposition of protoplasm (anabolic effect). In adult women, with doses of estrogen 2-10 times greater than used here, the anabolic effect was 9-27 g protoplasm $/ \mathrm{kg}$ BW $\times 10^{-1}$ per day (according to application of equations in footnote 3 to data in references 19 and 20). (b) Deposition of bone. In the same experiments with adult women, with doses of estrogen 2-10 times greater than in the present study, the increment in bone mass was $0.5-1 \mathrm{~g} / \mathrm{kg} \mathrm{BW} \times 10^{-1}$ per day. (c) Accumulation of EF. In the same studies with adult women, this effect ranged between 96 and $132 \mathrm{~g} \mathrm{EF} / \mathrm{kg} \mathrm{BW} \times 10^{-1}$ per day.

Tables II and III show that in normal boys, at a dose $\frac{1}{2}$ to $\frac{1}{10}$ those used tested previously on adult women, estrogens caused a significant increase in EF, but no detectable increment in protoplasm or in bone. Contrastingly, in all seven boys with dystrophy, estrogens regularly stimuated deposition of protoplasm and expansion of EF. The average response consisted of $+29 \mathrm{~g}$ protoplasm $/ \mathrm{kg} \mathrm{BW} \times 10^{-1}$ per day and $+56 \mathrm{~g} \mathrm{EF} / \mathrm{kg} \mathrm{BW}$ $\times 10^{-1}$ per day. The former effect was $1-3$ times greater than that previously observed in adult women at the higher estrogen doses, and 7 times greater than any anabolic effect produced with estrogens in the present experiments in normal boys (Table III). The EF effect was $\frac{1}{2}$ to $\frac{1}{3}$ as great as that observed before in adult women at the higher dosages, and did not differ significantly from the EF effect observed here in the normal boys.

Thus the boys with Duchenne dystrophy are hyperresponsive to the anabolic effect of estrogens. The mechanism for this hyperresponsiveness can only be speculated upon at present. One manifestation of abnormality in the muscle cells of the Duchenne patient may be intrinsic hypersensitivity to estrogens, which have only weak anabolic effects on normal muscle cells. Alternatively, the greater anabolic effect of estrogens in these patients may result from summation of $(a)$ a weak intrinsic anabolic effect of the estrogen, plus $(b)$ peripheral inhibition by the estrogen of a catabolic effect of endogenous HGH on the dystrophic muscle cells. Finally, the hyperresponsiveness to pharmacologic doses of estrogen may be a nonspecific consequence of muscle wasting in prepubertal boys, rather than a unique manifestation of the Duchenne-dystrophic state.

\section{REFERENCES}

1. Rudman, D., S. B. Chyatte, J. H. Patterson, G. G. Gerron, I. O'Beirne, J. Barlow, P. Ahmann, A. Jordan, and R. C. Mosteller. 1971. Observations on the responsiveness of human subjects to human growth hormone: 
effects of endogenous growth hormone deficiency and myotonic dystrophy. J. Clin. Invest. 51 : 1941.

2. Walton, J. N., F. J. Nattrass. 1954. On the classification, natural history and treatment of the myopathies. Brain. 77: 12.

3. Merimee, J. T., I. Rabinowitz, L. Riggs, J. A. Burgess, D. C. Rimoin, and V. A. McKusick. 1967. Plasma growth hormone after arginine infusion. N. Engl. J. Med. 276: 434.

4. Kleiber, M. 1961. The Fire of Life. An Introduction to Animal Energetics. John Wiley \& Sons, Inc., New York. 177.

5. Marsh, W. A., B. Fingerhut, and E. Kirsch. 1957. Determination of urea nitrogen with the diacetyl method and an automatic dialyzing apparatus. Amer. J. Clin. Pathol. 28: 681.

6. Chaney, A. L., and E. P. Marback. 1962. Modified reagents for determination of urea and ammonia. Clin. Chem. 8: 130 .

7. Rosalski, S. B. 1967. An improved procedure for serum creatine phosphokinase determination. J. Lab. Clin. Med. $69: 696$.

8. Wacker, W. E. C., D. D. Ulmer, and B. L. Vallee. 1956. Metalloenzymes and myocardial infarction. $N$. Engl. J. Med. 255: 449.

9. Lilienfeld, A. M., M. Jacobs, and M. Willis. 1954. A study of the reproducibility of muscle testing and certain other aspects of muscle scoring. Physical Therapy Review. 34 : 279.

10. Swinyard, C. A., G. C. Deaver, and L. Greenspan. 1957. Gradients of functional ability of importance in rehabilitation of patients with progressive muscular and neuromuscular diseases. Arch. Phys. Med. Rehabil. 38: 574.

11. Reifenstein, E. C., F. Albright, and S. Wells. 1945. The accumulation, interpretation and presentation of data pertaining to metabolic balances, notably those of calcium, phosphorus and nitrogen. J. Clin. Endocrinol. Metab. 5 : 3567.

12. Agna, J. W., H. C. Knowles, Jr., and G. Alverson. 1958. The mineral content of normal human bone. $J$. Clin. Invest. $37: 1357$.

13. Horvath, B., D. J. Cummings, and G. M. Shy. 1950. Muscular dystrophy: cation concentrations in residual muscle. J. Appl. Physiol. 8 : 22.
14. Felig, P. E. Marliss, and G. F. Cahill, Jr. 1969. Interaction of adipokinetic and protein-sparing effects of human growth hormone in fasting man. Presented at the 51st annual meeting of the Endocrine Society, New York, June 27-29.

15. Simon, E. J., C. S. Gross, and I. M. Lessell. 1962. Turnover of muscle and liver proteins in mice with hereditary muscular dystrophy. Arch. Biochem. Biophys. 96: 41 .

16. Kruh, J., J. C. Dreyfus, G. Schapira, and G. O. Gey, Jr. 1960. Abnormalities of muscle protein metabolism in mice with muscular dystrophy. J. Clin. Invest. 39: 1180.

17. Coleman, D. L., and M. E. Ashworth. 1959. Incorporation of glycine-1-C $\mathrm{C}^{\mathbf{1 4}}$ into nucleic acids and proteins of mice with hereditary muscular dystrophy. Amer. J. Physiol. 197 : 839.

18. Watts, D. C., and J. D. Reid. 1969. Comparison of the protein-synthesizing machinery in the skeletal muscle of normal and dystrophic Bar Harbor mice. Biochem. J. $115: 377$.

19. Weinstock, I. M., S. Epstein, and A. T. Milhorat 1958. Enzyme studies in muscular dystrophy. III. In hereditary muscular dystrophy in mice. Proc. Soc. Exp. Biol. Med. 99 : 272.

20. Berlingult, L., and U. Srivastava. 1966. Proteolytic enzymes in normal and dystrophic mouse muscle. Can. $J$. Biochem. $44: 613$.

21. Kostyo, J. L. 1968. The anabolic effects of pituitary growth hormone. International Symposium on the Pharmacology of Hormonal Polypeptides, Milan, 1967. Pharmacology of hormonal polypeptides and proteins; proceedings. In Advances in Experimental Medicine and Biology. N. Back, L. Martini, and R. Paoletti, editors. Plenum Publishing Corporation, New York. 2: 456.

22. Schwartz, E., E. Wiedemann, S. Simon, and $M$. Schiffer. 1969. Estrogenic anatagonism of metabolic effects of administered growth hormone. J. Clin. En docrinol. Metab. 29: 1176.

23. Knowlton, K., A. T. Kenyon, I. Sandiford, G. Lotwin, and R. Fricker. 1942. Comparative study of metabolic effects of estradiol benzoate and testosterone propionate in man. J. Clin. Endocrinol. Metab. 2: 671.

24. Reifenstein, E. C., and F. Albright. 1947. The metabolic effects of steroid hormones in osteoporosis. J. Clin. Invest. 26: 24. 